\title{
Influence of Surface Treatment of Steel Adherends on Shear Strength of Filled Resins
}

\section{Petr Valášek}

Faculty of Engineering, Czech University of Life Sciences Prague. Kamýcká 129, 165 21, Prague. Czech Republic. Email: valasekp@tf.czu.cz

\begin{abstract}
Adhesion of resins and adhesives to adherend is one of the important characteristics, including the area where the resin or adhesive is filled with particulate fillers in order to optimize this adhesion, achieve other mechanical characteristics or in order to reduce the price of the resulting resin or adhesive. When discussing filled resins with particulate fillers, these materials can be defined as a polymer composite systems. Surface treatment of adherend before applying such a filled resin, is crucial to the overall strength of this interface. Blasting is commonly used kind of surface treatment of metal adherends. Properly chosen blasting conditions and achieved roughness parameters are crucial to the overall strength. The experiment describes the impact of the changing conditions of blasting on the shear strength of epoxy resins filled with glass powder. The results of the experiment show that the highest shear strength on steel adherend was achieved when the surface was blasted at an angle of $60-90^{\circ}(12.93$ $\pm 0.62 \mathrm{MPa})$. The roughness parameters $\mathrm{Ra}$ and $\mathrm{Rz}$ were influenced by a specific kind of blasting material $\left(\mathrm{Al}_{2} \mathrm{O}_{3}\right.$ F80 and glass beads B10), which has also a considerable influence on shear strength.
\end{abstract}

Keywords: Blasting, corundum, epoxy resin, glass beads, glass powder.

\section{Acknowledgement}

The results were supported by the grant IGA TF 2015 (31140/1312/3107): Optimizing of the properties of resins and adhesives filled with organic and anorganic microparticles determined with experimental approach.

\section{References}

[1] NIELSEN, P.O. (1982). Properties of epoxy resins, hardners, and modifiers. In: Adhesives Age, Vol. 25, No. 4, pp. $42-46$.

[2] MLEZIVA, J. (1993). Polymery: Výroba, Struktura, Vlastnosti a Použití, 1. Ed. Prague: Sobotáles, 537 p.

[3] MÜLLER, M. (2011). Polymeric composites based on $\mathrm{Al}_{2} \mathrm{O}_{3}$ reinforcing particles. In: 10th International Scientific Conference on Engineering for Rural Development, Jelgava, pp. 423 - 427.

[4] LI, M., YUAN, C., et al. (2012). Evolution of the wettability between carbon fiber and epoxy as a function of temperature and resin curing. In: Journal of Applied Polymer Science, Vol. 128, No. 6, pp. 4095 - 4101.

[5] MÜLLER, M. (2014). Influence of ahesives storing temperature on adhesive bond strength. In: Manufacturing Technology. Vol. 14, No. 1, pp. $71-75$.

[6] MÜLLER, M., VALÁŠEK, P. (2013). Comparison of variables influence on adhesive bonds strength calculations. In: Manufacturing Technology. Vol. 13, No. 2, pp. $205-210$.

[7] RUDAWSKA, A. (2014). Selected aspects of the effect of mechanical treatment on surface roughness and adhesive joint strength of steel sheets. In: International Journal of Adhesion and Adhesives, Vol. 50, pp. 253 - 243.

[8] PIZZI, A., MITTAL, K.L. (2003). Handbook of Adhezive Technology, Marcel Dekker- Second edition, Revised and Expanded, New York, 1024 p.

[9] TENG, J.G., FERNANDO, D., YU, T., ZHAO, X.L. (2011). Treatment of steel surfaces for effective adhesive bonding. In: Advances in FRP Composites in Civil Engineering - Proceedings of the 5th International Conference on FRP Composites in Civil Engineering, CICE 2010. pp. 865 - 868.

[10] MARGHITU, D.B. (2001). Mechanical engineers handbook, Auburn University Alabama, Alabama, 864 p.

[11] KINLOCH, A.J, LEE, J.H., et al. (2003). Toughening structural adhesives via nano- and micro-phase inclusions. In: Journal of Adhesion, Vol. 79, No. 8-9, pp. $867-873$.

[12] ZHAI, L., LING, G., LI, J., WANG, Y. (2006). The effect of nanoparticles on the adhesion of epoxy adhesive. In: Materials Letters, Vol. 60, No. 25-26, pp. $3031-3033$.

[13] VALÁŠEK, P., MÜLLER, M. (2013). Changes of Polyurethane Mechanical Properties Filled with Glass Powder. In: Manufacturing Technology, Vol. 13, No. 4, pp. 563 - 568. 
[14] VEŘEJNÝ INFORMAČNÍ SYSTÉM ODPADOVÉHO HOSPODÁŘSTVÍ, VISOH [online]. 2014, [2014-10-11]. Avaiable at: $<\mathrm{http}: / / \mathrm{http}: / /$ isoh.cenia.cz/groupisoh/>

[15] REFAGLASS, A.S., skelná moučka [online]. 2014, [2014-09-10]. Avaiable at: <http://www.refaglass.cz/sklenena-moucka-019>

[16] NOVÁK, M. (2011). Surface duality hardened steels after grinding. In: Manufacturing technology, Vol. 11, pp. $55-59$.

[17] AFFATATO, S., RUGGIERO, A., et al. (2013). On the roughness measurement of the knee femoral components. In: BIOMODLORE 2013 Palanga (LT) 20-22 Sept. 2013 Vilnius Vilnius Gediminas Technical University Press Technica (Sauletekio al.11, LT-10223, Vilnius, Lithuania.), pp. 16 -18.

[18] ČSN EN 1465. (1997). Adhesives - Determination of tensile lap-shear strength of rigid-to-rigid bonded assemblies. Czech Standards Institute.

[19] VALÁŠEK, P., MÜLLER, M. (2012). Polymeric particle composites with filler saturated matrix. In: Manufacturing Technology, Vol. 12, No. 13, pp. $272-276$.

\section{Paper number: M201581}

Copyright $(\odot)$ 2015. Published by Manufacturing Technology. All rights reserved. 